Ross English

\title{
The
}

United States Congress $r \neq x+x y$

Tन .

11.
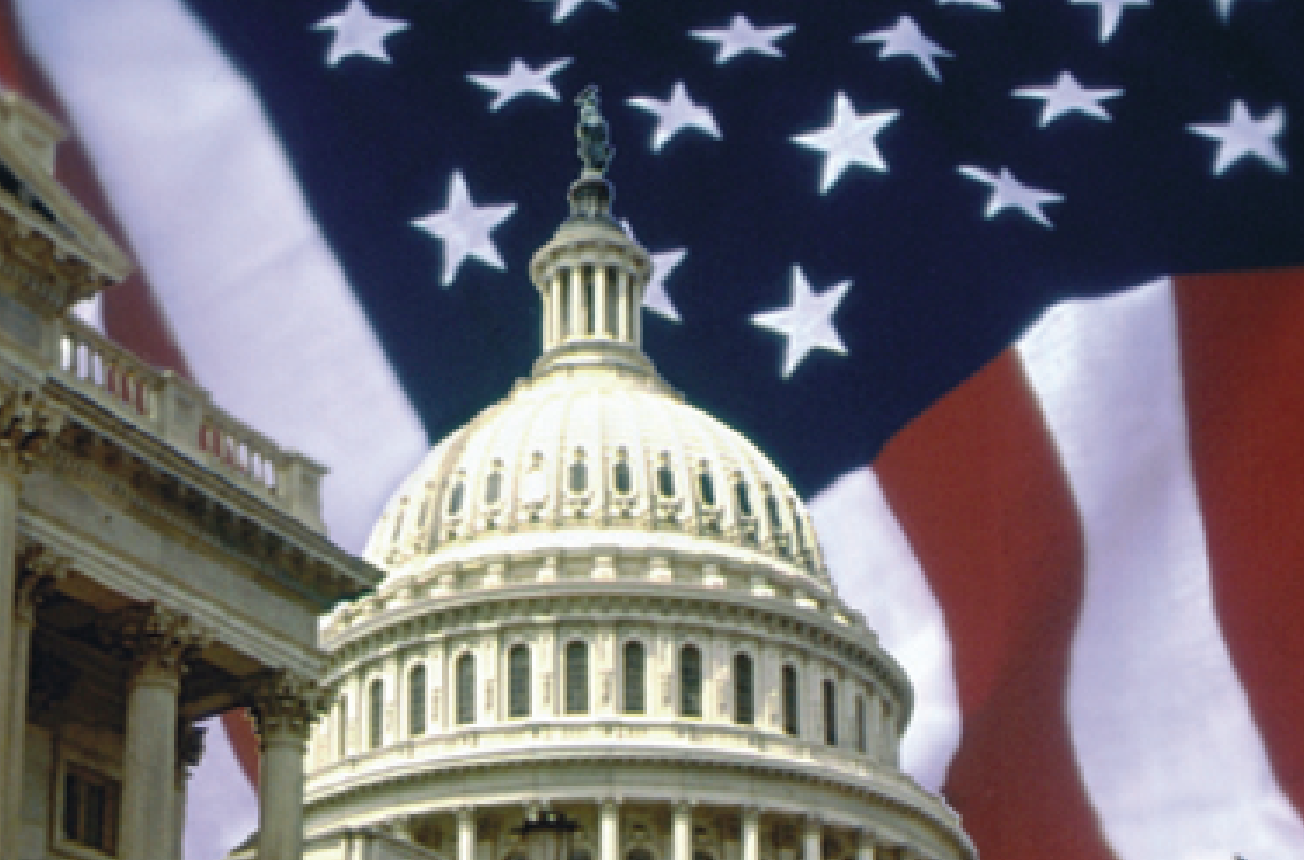

1 iाIIIIMIII)

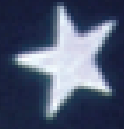

जin

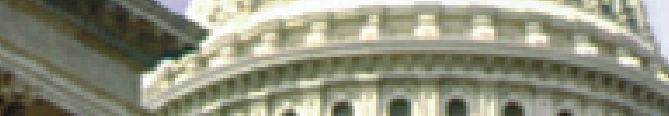

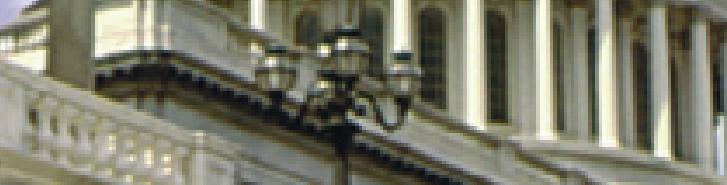

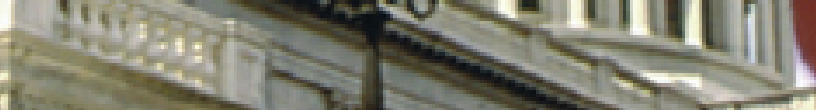

HAw

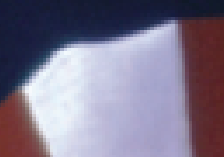




\section{The United States Congress}

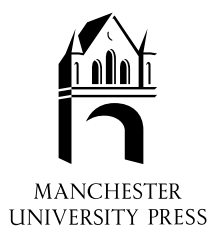


Ross M. English - 9781526120687

Downloaded from manchesterhive.com at $04 / 26 / 2023$ 03:05:49PM 
Ross M. English

\section{The United States Congress}

Manchester University Press

Manchester and New York

distributed exclusively in the USA by Palgrave 
Copyright $($ ) Ross M. English 2003

The right of Ross M. English to be identified as the author of this work has been asserted by him in accordance with the Copyright, Designs and Patents Act 1988.

Published by Manchester University Press Oxford Road, Manchester M13 9NR, UK and Room 400, 175 Fifth Avenue, New York, NY 10010, USA www.manchesteruniversitypress.co.uk

Distributed exclusively in the USA by Palgrave, 175 Fifth Avenue, New York, NY 10010, USA

Distributed exclusively in Canada by UBC Press, University of British Columbia, 2029 West Mall, Vancouver, BC, Canada V6T 1Z2

British Library Cataloguing-in-Publication Data

A catalogue record for this book is available from the British Library

Library of Congress Cataloging-in-Publication Data applied for

ISBN 0719063086 hardback

0719063094 paperback

First published 2003

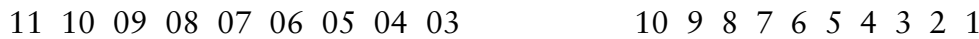

Typeset in Sabon

by Servis Filmsetting Ltd, Manchester

Printed in Great Britain

by Biddles Ltd, Guildford and King's Lynn 